\title{
Fatty acid profile of duodenal digesta and of meat of feedlot beef cattle fed diets containing different levels of concentrate
}

\section{Perfil de ácidos graxos da digesta duodenal e da carne de bovinos alimentados em confinamento com diferentes níveis de concentrado na dieta}

\author{
Regis Luis Missio ${ }^{1 *}$; Luis Fernando Glasenapp de Menezes²; Ivan Luiz Brondani ${ }^{3}$; \\ José Laerte Nörnberg ${ }^{3}$; Paulo Santana Pacheco ${ }^{3}$; Fernando Kuss ${ }^{2}$; \\ Magali Floriano da Silveira ${ }^{2}$; João Restle ${ }^{4}$
}

\begin{abstract}
The objective of this study was to evaluate the fatty acid profile of duodenal digesta (experiment I) and of meat of beef cattle (experiment II) fed diets containing different levels of concentrate (220, 400,590 and $790 \mathrm{~g}$ of concentrate $/ \mathrm{kg}$ of dry matter of the diets). The experiment I was conducted with four Charolais-Nellore steers $(460 \pm 18.2 \mathrm{~kg}$ of BW), with a T-shaped duodenal cannula, using a double $4 \times 4$ Latin square as an experimental design. In experiment II, 16 crossbred Charolais-Nellore young bulls $(192.44 \pm 18.2 \mathrm{~kg}$ of BW) were randomly distributed in the experimental treatments $(220$, 400,590 and $790 \mathrm{~g}$ of concentrate/ $\mathrm{kg}$ of dry matter of the diets). The diets were isonitrogenous (120 $\mathrm{g}$ of crude protein $/ \mathrm{kg}$ of dry matter). The intramuscular fat content was used as a covariant for the statistical analysis of the meat fatty acid profile. The duodenal content of fatty acid C17:0 decreased with increase of concentrate levels, while its content in the meat presented a quadratic variation with the increase of the concentrate levels of the diets, being the lowest values observed for the diet with $400 \mathrm{~g}$ of concentrate. The duodenal content of fatty acid C18:1 trans-11 decreased, whereas the content of this fatty acid in the meat increased with the increase of the dietary concentrate levels. The increase in the level of concentrate reduced the content of polyunsaturated fatty acids $C 18: 3 n-3, C 20: 3 n-6, C 20: 4 n-6$, and C20:5 n-3 EPA in both the duodenal digesta and meat. No difference was observed in the $n-6 / n-3$ fatty acids ratio (mean of 13.96) of the meat between diets. The elevation of the level of concentrate in confinement diets reduces the nutraceutical quality of the meat of Charolais-Nellore young bulls slaughtered at 14-16 months of age due to the reduction of the polyunsaturated fatty acids content important for human health.
\end{abstract}

Key words: Linoleic. Oleic. Polyunsaturated. Saturated. Vaccenic.

1 Prof., Departamento de Agronomia, Universidade Tecnológica Federal do Paraná, UTFPR, Pato Branco, PR, Brasil. E-mail: regisluismissio@gmail.com

2 Profs., Programa de Pós-Graduação em Zootecnia, UTFPR, Dois Vizinhos, PR, Brasil. E-mail: luismenezes@utfpr.edu.br; fernandokuss@utfpr.edu.br; magalisilveira@utfpr.edu.br

3 Profs., Departamento de Zootecnia, Universidade Federal de Santa Maria, UFSM, Santa Maria, RS, Brasil. E-mail: ivanbrondani@ gmail.com; jnornberg@gmail.com; pacheco.dz.ufsm@hotmail.com

4 Prof., Programa de Pós-Graduação em Ciência Animal, Universidade Federal de Goiás, UFG, Goiânia, GO, Brasil. Bolsista de Produtividade em Pesquisa do CNPq, Nível 1D. E-mail: jorestle@terra.com.br

* Author for correspondence 


\section{Resumo}

O objetivo deste trabalho foi avaliar o perfil de ácidos graxos da digesta duodenal (experimento I) e da carne (experimento II) de bovinos confinados com dietas contendo níveis de concentrado (220, 400, 590 e $790 \mathrm{~g}$ de concentrado/ $\mathrm{kg}$ de matéria seca da dieta). O experimento I foi conduzido com quatro novilhos Charolês-Nelore ( $460 \pm 18,2 \mathrm{~kg}$ de PV), com cânula duodenal em forma de T, utilizando-se um duplo quadrado latino $4 \times 4$ como delineamento experimental. No experimento II, 16 tourinhos mestiços Charolês-Nelore $(192,44 \pm 18,2 \mathrm{~kg}$ de PV) foram distribuídos aleatoriamente nos tratamentos experimentais $(220,400,590$ e $790 \mathrm{~g}$ de concentrado/kg de matéria seca da dieta). As dietas foram isonitrogenadas ( $120 \mathrm{~g}$ de proteína bruta/ $\mathrm{kg}$ de matéria seca). O conteúdo de gordura intramuscular foi utilizado como covariável para a análise estatística do perfil de ácidos graxos da carne. O conteúdo do ácido graxo C17:0 da digesta duodenal foi reduzido, enquanto seu conteúdo na carne apresentou variação quadrática com o avanço do teor de concentrado das dietas, sendo os menores valores observados para a dieta com $400 \mathrm{~g}$ de concentrado. O conteúdo duodenal do ácido graxo C18:1 trans-11 diminuiu, enquanto o conteúdo desse ácido graxo na carne aumentou com o aumento dos níveis de concentrado das dietas. $\mathrm{O}$ aumento do nível de concentrado reduziu o teor de ácidos graxos poli-insaturados C18:3 $n-3$, C20:3 n-6, C20:4 n-6 e C20:5 n-3 EPA na digesta duodenal e na carne. Nenhuma diferença foi observada na proporção de ácidos graxos $n-6 / n-3$ (média de 13,96) da carne entre as dietas. A elevação do nível de concentrado em dietas de confinamento reduz a qualidade nutracêutica da carne de tourinhos Charolês-Nelore abatidos com 14-16 meses de idade em razão da redução do teor de ácidos graxos poliinsaturados importantes para a saúde humana.

Palavras-chave: Linoleico. Oleico. Poli-insaturados. Saturados. Vaccênico.

\section{Introduction}

Feed is one of the main determinants of the fatty acid profile of beef cattle meat (SMITH et al., 2009). In general, feedlot termination increases marbling, resulting in higher saturated fatty acid content than that in pasture-finished beef(BRESSAN et al., 2011). However, the physicochemical characteristics that determine the sale of beef (color and marbling), and consumer loyalty (tenderness) are positively associated with subcutaneous and intramuscular fat (KOOHMARAIE et al., 1996), that are benefited by feedlot-diets.

In Brazil, the number of animals finished in feedlots have more than doubled in the last 15 years, boosting the use of high-concentrate diets. Increasing levels of concentrate in the diet can alter the nutritional quality of meat by reducing fatty acid biohydrogenation with the decline in rumen $\mathrm{pH}$ (SMITH et al., 2009). In addition, the increase in concentrate levels reduces the age of slaughter, which makes the fatty acid profile of the meat less saturated (DUCKETT et al., 1993). This is because the polyunsaturated fatty acids related to the phospholipid fraction decreases with increase in age (XUE et al., 2015). Most of the results found in the literature, however, are confined to assessing the fatty acid profile of the meat of grass-fed and grain-fed animals, which means there is a lack of information on rumen metabolism. There is also a lack of information on the profile of fatty acids in the meat of young bulls, characterized by the production of lean meat with a fatty acid profile more unsaturated in relation to castrated animals (MISSIO et al., 2017).

The objective of the present study was to evaluate the fatty acid profiles of duodenal digesta and meat of beef cattle fed diets containing different levels of concentrate.

\section{Material and Methods}

This study was conducted in accordance with the recommendations of the Brazilian Committee for Animal Care and Experimentation. 
Four diets containing concentrate levels of 220, 400, 590, and $790 \mathrm{~g} \mathrm{~kg}^{-1}$ dry matter (DM) were assessed. The diets were isonitrogenous $\left(120 \mathrm{~g} \mathrm{~kg}^{-1}\right.$ $\mathrm{DM})$, and primarily consisted of corn silage (33\% of grain in MS), ground corn grain, wheat bran, and soybean meal (Table 1).

The first experiment was conducted using four crossbred Charolais-Nellore calves with a mean body weight of $460 \pm 18.2 \mathrm{~kg}$. The animals were fitted with T-shaped duodenal cannulas to determine the fatty acid profile of the duodenal digesta. The adopted experimental design was the $4 \times 4$ Latin square (four diets and four periods). The animals were kept in individual stalls $\left(10 \mathrm{~m}^{2}\right)$ with feeders and water freely available. Before commencing the experiment, the animals were examined for the presence of parasites. Body weight of animals was measured at the beginning and end of each experimental period (15 days), after water and solids fasting for 14 hours.

Table 1. Composition of diets.

\begin{tabular}{|c|c|c|c|c|}
\hline \multirow{2}{*}{ Items, $\mathrm{g} / \mathrm{kg}$ of $\mathrm{DM}$} & \multicolumn{4}{|c|}{ Concentrate levels, g/kg DM } \\
\hline & 220 & 400 & 590 & 790 \\
\hline \multicolumn{5}{|c|}{ Proportion of ingredients } \\
\hline Corn silage & 780.00 & 600.00 & 410.00 & 210.00 \\
\hline Ground corn grain & 59.10 & 94.30 & 293.20 & 491.50 \\
\hline Wheat bran & 107.50 & 242.70 & 247.90 & 269.70 \\
\hline Soybean bran & 35.30 & 41.10 & 25.80 & 3.20 \\
\hline Limestone & 9.20 & 14.60 & 16.30 & 19.20 \\
\hline Salt & 3.30 & 3.20 & 3.20 & 3.20 \\
\hline Urea & 5.10 & 3.70 & 3.20 & 2.70 \\
\hline Rumensin ${ }^{@}$ & 0.20 & 0.20 & 0.20 & 0.30 \\
\hline Ammonium sulfate & 0.30 & 0.20 & 0.20 & 0.20 \\
\hline \multicolumn{5}{|c|}{ Chemical composition } \\
\hline Dry matter $(\mathrm{g} / \mathrm{kg})$ & 394.70 & 500.60 & 610.00 & 717.30 \\
\hline Mineral matter & 62.40 & 59.30 & 57.20 & 54.60 \\
\hline Crude protein & 112.00 & 125.00 & 121.00 & 118.00 \\
\hline Extract ether & 24.50 & 26.40 & 26.50 & 26.80 \\
\hline Neutral detergent fiber & 480.00 & 438.00 & 381.00 & 287.00 \\
\hline Total carbohydrates & 801.10 & 789.30 & 795.30 & 800.60 \\
\hline Nom-fibrous carbohydrates & 321.10 & 351.30 & 414.30 & 513.60 \\
\hline Digestible energy (Mcal $/ \mathrm{kg}$ ) & 2.35 & 2.41 & 2.55 & 2.68 \\
\hline \multicolumn{5}{|c|}{ Fermentation kinetics } \\
\hline Total gas production, $\mathrm{mL}$ & 172.00 & 173.00 & 185.10 & 194.60 \\
\hline Rate of degradation, $\%$ & 0.027 & 0.030 & 0.034 & 0.043 \\
\hline
\end{tabular}

$\mathrm{DM}=$ dry matter.

The period of adaptation to the facilities and diets was seven days. Feed was supplied at will twice a day (8:00 A.M. and 5:00 P.M.), with 10\% retention of the leftovers (dry matter basis). Dry matter intake was measured between the $7^{\text {th }}$ and $11^{\text {th }}$ day of each experimental period. After the $11^{\text {th }}$ day of the trial period, intake was restricted to $90 \%$ of voluntary consumption. Duodenal digesta collections occurred between the $14^{\text {th }}$ and $15^{\text {th }}$ day with 6-hour intervals for 24 hours. These samples were centrifuged $(1000 \times \mathrm{g}$ for 30 minutes $)$ and the supernatant was discarded. The solid part was dried 
in the oven with forced air circulation for 72 hours at $55^{\circ} \mathrm{C}$. The samples were subsequently ground (1 $\mathrm{mm}$ particle size) in a Wiley mill.

In the second experiment, 16 young crossbred Charolais-Nellore bulls were randomly distributed to four treatments. Before the trial period, the animals were checked for parasites, and allowed to adapt to the facilities and diets for 15 days. Initial mean age and body weight of the animals was 9.32 months and $192.44 \mathrm{~kg}$, respectively. The animals were confined in covered stalls $\left(12 \mathrm{~m}^{2}\right)$ with individual feeders and water freely available. Food was supplied ad libitum, twice a day (8:00 A.M. and 5:00 P.M).

Concentrate levels of 220, 400, 590, and $790 \mathrm{~g}$ were fed to the animals for a period of 199, 171, 140, and 140 days, respectively. The animals were slaughtered with a mean body weight of $400 \mathrm{~kg}$. The carcasses were identified, cleaned, and cooled $\left(2{ }^{\circ} \mathrm{C}\right)$ for 24 hours. The surface of the longissimus lumborum muscle between the $12^{\text {th }}$ and $13^{\text {th }}$ rib of the right carcass was checked for marbling by three trained evaluators. The following was found: 1 to $3=$ traces; 4 to $6=$ slight, 7 to $9=$ small; 10 to $12=$ modest; 13 to $15=$ moderate, and 16 to $18=$ abundant. The intramuscular fat of the animals fed diets with $220,400,590$, and $790 \mathrm{~g}$ of concentrate presented a marbling score of 4.5, 9.2, 5.5, and 5.2 points, respectively.

A sample of the longissimus lumborum, free of external fat, was collected from of the section between the $11^{\text {th }}$ and $13^{\text {th }}$ rib of the right carcasses. These samples were dried in an oven with forced air circulation at $55^{\circ} \mathrm{C}$ for 72 hours and ground $(1 \mathrm{~mm}$ particles) in a Wiley mill.

Total lipids from the feed and the duodenal digesta were extracted according to Bligh and Dyer (1959). The fatty acids were esterified according to the technique described by Hartman and Lago (1973), and analyzed in a gas chromatograph (Agilent, model HP6890) equipped with a flame ionization detector (FID) and Supelco SP2560 capillary column $(100 \mathrm{~m} \times 0.25 \mathrm{~mm} \times 0.2 \mu \mathrm{m})$. Injector and detector temperatures were maintained at $250^{\circ} \mathrm{C}$ and $280^{\circ} \mathrm{C}$, respectively. Temperature programming of the column started at $140^{\circ} \mathrm{C}$ for 5 minutes, with gradual increases of $4^{\circ} \mathrm{C}$ per minute to the final temperature of $240^{\circ} \mathrm{C}$. Carrier gas flow $\left(\mathrm{N}_{2}\right)$ was $30 \mathrm{~mL} / \mathrm{min}$. The injection volume was 1 $\mu \mathrm{L}$ with a split ratio of 1:50. The fatty acids were identified by comparing the retention time of the samples with known standards. Table 2 shows the fatty acid profile of the diets.

Table 2. Fatty acid content of diets.

\begin{tabular}{lcccc}
\hline \multirow{2}{*}{ Items, g/100 g fatty acid methyl esters } & \multicolumn{3}{c}{ Concentrate levels, g/kg DM } \\
\cline { 2 - 5 } C14:0 & 220 & 400 & 590 & 790 \\
C16:0 & 0.06 & 0.05 & 0.03 & 0.02 \\
C16:1 & 1.98 & 1.89 & 1.71 & 1.16 \\
C17:0 & 0.05 & 0.04 & 0.07 & 0.02 \\
C18:0 & 0.04 & 0.03 & 0.02 & 0.02 \\
C18:1 cis-9 & 0.41 & 0.42 & 0.69 & 0.72 \\
C18:2 cis-6 & 2.15 & 2.20 & 2.15 & 1.76 \\
C18:3 n-3 & 3.16 & 3.47 & 2.92 & 2.90 \\
C20:0 & 0.81 & 0.66 & 0.47 & 0.27 \\
C22:0 & 0.11 & 0.09 & 0.20 & 0.08 \\
C24:0 & 0.12 & 0.10 & 0.12 & 0.05
\end{tabular}


continuation

\begin{tabular}{lllll} 
Saturated fatty acids (SFA) & 2.88 & 2.72 & 2.65 & 1.66 \\
Monounsaturated fatty acids (MUFA) & 2.22 & 2.32 & 2.28 & 1.81 \\
Polyunsaturated fatty acids (PUFA) & 3.97 & 4.17 & 3.51 & 3.21 \\
Unsaturated fatty acids (UFA) & 6.19 & 6.48 & 5.78 & 5.01 \\
\hline
\end{tabular}

$\mathrm{DM}=$ dry matter.

Beef lipids were extracted using the modified method of Folch et al. (1957), in which $0.5 \mathrm{~g}$ of lipids are placed in glass tubes with a mixture of 10 $\mathrm{ml}$ chloroform/methanol (2:1). After 24 hours, we added $10 \mathrm{~mL}$ of distilled water and the tubes were centrifuged at $500 \times \mathrm{g}$ for 5 minutes. The organic phase (chloroform) was transferred to test tubes with lids, and placed in a water bath at $40^{\circ} \mathrm{C}$ with compressed air flow until only the lipids remained. For fatty acid methylation, $500 \mathrm{ml}$ of $\mathrm{KOH} 0.4 \mathrm{M}$ in methanol were added and the tubes were left in a water bath at $60^{\circ} \mathrm{C}$ for 2 hours. The tubes were cooled to room temperature, after which $1.5 \mathrm{~mL}$ of $\mathrm{H}_{2} \mathrm{SO}_{4} 1 \mathrm{M}$ in methanol were added. The tubes remained in the water bath at $60^{\circ} \mathrm{C}$ for over 2 hours and were subsequently cooled. Following this, $2 \mathrm{~mL}$ of n-hexane was added to retrieve the methyl esters of the fatty acids.

Fatty acids were determined in gas chromatograph equipped with a flame ionization detector and Supelco SP2340 capillary column $(60 \mathrm{~m} \times 0.25 \mathrm{~mm} \times 0.2 \mu \mathrm{m})$. Detector and injector temperatures were $260^{\circ} \mathrm{C}$ and $240^{\circ} \mathrm{C}$, respectively. Temperature programming of the column started at $140^{\circ} \mathrm{C}$ for 5 minutes, with gradual increases of $4^{\circ} \mathrm{C}$ per minute to the final temperature of $240^{\circ} \mathrm{C}$. Carrier gas flow $\left(\mathrm{N}_{2}\right)$ was $17 \mathrm{~mL} / \mathrm{min}$. The injection volume was $0.05 \mu \mathrm{L}$ with a split ratio of $1: 100$. The peaks were identified and fatty acids were quantified by comparing the retention times and peak area of the fatty acids with the fatty acid standards (Supelco 37 components FAMEs Mix, ref. 47885-U).

The data was subjected to analysis of variance and regression $(\alpha=0.05)$ using the mixed model methodology (LITTELL et al., 2006), considering the treatments as fixed effect and the animals as variable effect. In experiment-1, the assessment periods were analyzed as repeated measures in time. The AIC (Akaike's Information Criterion) was used to select the ideal regression model.

The mathematical model used in experiment- 1 is represented by:

$$
\mathrm{Y}_{\mathrm{ijk} \mathrm{k}}=\mu+\mathrm{T}_{i}+\mathrm{R}_{j}\left(\mathrm{~T}_{i}\right)_{+} \mathrm{M}_{k}+\mathrm{T}_{i}^{*} \mathrm{M}_{k}+\mathrm{e}_{\mathrm{ijkl},}
$$

where: $\mu=$ general mean; $\mathrm{T}_{i}=$ effect of diets; $\mathrm{R}_{J}\left(\mathrm{~T}_{i}\right)=$ effect of repetition within treatment; $\mathrm{M}_{k}=$ period effect; $\mathrm{T}_{i}^{*} \mathrm{M}_{k}=$ interaction between diets and period; and $\mathrm{e}_{\mathrm{ijkl}}=$ experimental error.

The mathematical model used in experiment -2 is represented by:

$$
\mathrm{Y}_{\mathrm{ijk}}=\mu+\mathrm{T} i+\mathrm{M}_{\mathrm{j}}+\mathrm{e}_{\mathrm{ijk}}
$$

where: $\mu=$ general mean; $\mathrm{T}_{i}=$ effect of diets; $\mathrm{M}_{j}$ $=$ effect of the covariate (intramuscular fat); and $\mathrm{e}_{\mathrm{ijk}}=$ experimental error. When not significant, the effect of the covariate was removed from the model.

\section{Results and Discussion}

The dry matter intake (DMI) and ether extract intake (EEI), determinants for input of fatty acids, decreased linearly $(\mathrm{P}<0.05)$ with the increase in concentrate levels (Table 3 ). These results can be attributed to attendance of energy demand of the animals due to the higher energy concentration of the diets with higher concentrate levels. The reduction in DMI with the elevation in dietary density is well documented in the literature (KREHBIEL et al., 2006). However, it should be noted that, according to Restle et al. (2012), DMI tends to increase with the inclusion of concentrate in the diet, while the proportion of silage (medium to high quality) is 
higher than that of concentrate. However, when the fraction of concentrate is higher than that of forage, according to these researchers, DMI tends to approach the inflection point of the curve, from which it decreases as result of the digestible energy intake and attendance of physiological energy of the animal.

The duodenal content of fatty acid C17:0 decreased linearly $(\mathrm{P}<0.05)$ as the levels of concentrate in the diet increased (Table 3). The duodenal content of C14:0 fatty acid, similarly, tended ( $\mathrm{P}=0.066)$ to decrease as the levels of concentrate in the diets increased. The dietary content of fatty acids C14:0 and C17:0, contrary to the other saturated fatty acids (SFA), was reduced by half, as the levels of concentrate in the diets were increased (Table 2), which explains the reduction of these fatty acids in the duodenal digesta. It is worth mentioning that the increases of the fatty acid C17:0 in the rumen content are usually associated with $\alpha$-oxidation of fatty acid $\mathrm{C} 18: 0$ and/or de novo synthesis from propionate (JEKINS et al., 2015), which increased as the levels of concentrate in the diet increased (PEDREIRA et al., 2013). The present study, however, clearly showed that the level of fatty acid $\mathrm{C} 17: 0$ of the duodenal digesta was the result of diet composition and DMI.

Table 3. Dry matter and ethereal extract intake, and duodenal fatty acid profile of yound bulls fed concentrate levels.

\begin{tabular}{|c|c|c|c|c|c|c|c|c|}
\hline \multirow{2}{*}{$\begin{array}{c}\text { Items, } g / 100 \mathrm{~g} \text { fatty acid } \\
\text { methyl esters }\end{array}$} & \multicolumn{4}{|c|}{ Concentrate levels, g/kg DM } & \multirow{2}{*}{ SE } & \multicolumn{3}{|c|}{$\mathrm{P}$ - value } \\
\hline & 220 & 400 & 590 & 790 & & $\mathrm{~L}$ & $\mathrm{Q}$ & $\mathrm{C}$ \\
\hline \multicolumn{9}{|c|}{ Nutrients intake } \\
\hline Dry matter, $\mathrm{kg} /$ day & 13.25 & 10.99 & 10.77 & 9.11 & 17.59 & 0.005 & 0.735 & 0.389 \\
\hline Extract ether, kg/day & 0.32 & 0.29 & 0.28 & 0.25 & 17.29 & 0.044 & 0.955 & 0.609 \\
\hline \multicolumn{9}{|c|}{ Saturated fatty acids (SFA) } \\
\hline $\mathrm{C} 14: 0$ & 0.66 & 0.57 & 0.53 & 0.54 & 21.21 & 0.066 & 0.273 & 0.945 \\
\hline C16:0 & 14.48 & 14.45 & 14.55 & 14.53 & 7.17 & 0.903 & 0.992 & 0.919 \\
\hline C17:0 & 0.73 & 0.65 & 0.56 & 0.50 & 13.23 & 0.003 & 0.808 & 0.941 \\
\hline C18:0 & 59.49 & 59.69 & 65.89 & 63.58 & 4.78 & 0.023 & 0.458 & 0.043 \\
\hline \multicolumn{9}{|c|}{ Monounsaturated fatty acids (MUFA) } \\
\hline $\mathrm{C} 18: 1$ cis-9 & 5.97 & 5.60 & 4.70 & 5.04 & 17.84 & 0.128 & 0.508 & 0.464 \\
\hline C18:1 trans -9 & 0.17 & 0.18 & 0.19 & 0.22 & 1.79 & 0.612 & 0.883 & 0.960 \\
\hline C18:1 trans-11 & 2.51 & 2.10 & 1.57 & 1.68 & 16.83 & 0.003 & 0.141 & 0.313 \\
\hline C20:1 & 0.17 & 0.38 & 0.02 & 0.00 & 4.57 & 0.222 & 0.486 & 0.203 \\
\hline \multicolumn{9}{|c|}{ Polyunsaturated fatty acids (PUFA) } \\
\hline $\mathrm{C} 18: 2$ trans -6 & 0.99 & 0.89 & 0.75 & 0.74 & 18.49 & 0.009 & 0.484 & 0.574 \\
\hline $\mathrm{C} 18: 3 n-3$ & 0.05 & 0.20 & 0.04 & 0.06 & 2.75 & 0.352 & 0.501 & 0.356 \\
\hline $\mathrm{C} 18: 3 n-6$ & 0.96 & 0.94 & 0.91 & 0.88 & 11.00 & 0.141 & 0.977 & 0.952 \\
\hline C18:2 cis-9 trans -11 & 0.00 & 0.08 & 0.00 & 0.00 & 0.94 & 0.625 & 0.279 & 0.143 \\
\hline $\mathrm{C} 20: 3 n-6$ & 0.06 & 0.36 & 0.21 & 0.23 & 2.01 & 0.389 & 0.145 & 0.137 \\
\hline $\mathrm{C} 20: 4 n-6$ & 0.80 & 0.36 & 0.24 & 0.28 & 4.58 & 0.068 & 0.206 & 0.877 \\
\hline Total SFA & 81.37 & 81.85 & 87.19 & 85.86 & 2.70 & 0.005 & 0.497 & 0.021 \\
\hline Total MUFA & 8.9 & 8.45 & 6.51 & 6.94 & 14.44 & 0.007 & 0.406 & 0.101 \\
\hline Total PUFA & 2.89 & 2.89 & 2.15 & 2.19 & 14.44 & 0.052 & 0.834 & 0.156 \\
\hline Total UFA & 11.79 & 11.34 & 8.66 & 9.13 & 14.43 & 0.004 & 0.582 & 0.039 \\
\hline
\end{tabular}

Dry matter intake $(\mathrm{DMI})=14.2-0.06337 \mathrm{CL}$; Extract ether intake $(\mathrm{EEI})=0.34-0.00104 \mathrm{CL} ; \mathrm{C} 17: 0=0,8075-0,00394 \mathrm{CL}, \mathrm{C} 18: 0$ $=57.5538+0.09222 \mathrm{CL} ; \mathrm{C} 18: 1$ trans $-11=2.7162-0.01504 \mathrm{CL} ;$ Total SFA = 79.6963 + 0.09034CL; Total MUFA = $13.0012-$ 0.05439CL; Total unsaturated fatty acids $=13.0012$ - 0.05439CL; CL, concentrate level; SE, standard error; L, linear effect; Q, quadratic effect; $\mathrm{C}$, cubic effect. 
The content of fatty acid C18:0 and the sum of saturated fatty acids (SFA) of the duodenal digesta increased linearly $(\mathrm{P}<0.05)$ as the level of concentrate in the diet increased (Table 3). The total SFA of the duodenal digesta can be attributed to the dietary content of fatty acids C18:0 of the duodenal digesta, which represented more than $70 \%$ of saturated fatty acids. The increased content of fatty acid C18:0 of the duodenal digesta is attributed to its increasing concentration in the diets as the levels of concentrate increased. The flow of fatty acid $\mathrm{C} 18: 0$ from the rumen is several times greater than the amount consumed from biohydrogenation of unsaturated fatty acids (UFA) and polyunsaturated fatty acids (PUFA) with $18 \mathrm{C}$ (LOFTEN et al., 2014).

The duodenal content of fatty acids C18:1 trans-11 and C18:2 trans-6, and the sum of monounsaturated fatty acids (MUFA), PUFA, and UFA decreased linearly $(\mathrm{P}<0.05)$ with the increase concentrate levels in the diets (Table 3). The duodenal content of fatty acid C18:1 trans-11 can be attributed to the PUFA of the diets, which decreased with increasing levels of concentrate. Moreover, the content of fatty acid C18:1 trans-11 of the duodenal digesta can be associated with the negative effects of ruminal $\mathrm{pH}$ reduction on the bacteria responsible for rumen biohydrogenation, considering that fatty acid C18:1 trans-11 is an intermediary of the incomplete biohydrogenation of PUFA to fatty acid C18:0 (SMITH et al., 2009). Loor et al. (2004) observed a reduction in biohydrogenation and duodenal flow of fatty acid C18:1 trans-11 as the concentrate levels in diet increased, but no increase in fatty acid 18:2 cis9 trans-11 acid (CLA) was detected in the duodenal digesta even at the increased concentrate levels. On the other hand, the duodenal variation of fatty acid C18:2 trans- 6 , can be associated with a reduction in fatty acid C18:2 cis-6 in the diet (Table 2), whereby the first can be obtained by hydrogenation of the second (GLASSER et al., 2008). The similar content of other PUFAs of the duodenal digesta may be associated with their low dietary content. This, however, does not apply to the total of MUFA,
PUFA, and UFA as they are the sum of a group of fatty acids and, therefore, had a greater variation among diets. The reduced content of total MUFA, total PUFA, and total UFA in the duodenal digesta can be attributed to the fatty acid content of the diets.

The increasing levels of concentrate in the diets determined the quadratic variation $(\mathrm{P}<0.05)$ in the content of fatty acid C17:0 in the meat (Table 4), with the lowest values being observed in the diets with $400 \mathrm{~g}$ of concentrate. These results can be associated with de novo synthesis from propionate in the tissue (SMITH et al., 2009), which may have compensated for the reduced fatty acid content in the duodenal digesta when the concentrate fraction exceeded that of the silage fraction and propionate production became relevant. The increase in de novo synthesis of fatty acids $\mathrm{C} 15: 0$ and $\mathrm{C} 17: 0$ is indicated due to the increased dosage of these fatty acids in the tissues with respect to duodenal dosage (VLAEMINCK et al., 2006). The SFA of the odd chain type are important because they are associated with lowering the risk of developing multiple sclerosis, and act in a similar manner on the fluidity of membranes in relation to PUFA (JEKINS et al., 2015).

The sum of SFA of the meat, however, was not altered $(\mathrm{P}>0.05)$ by the diets (Table 4$)$. These results can be attributed to the similar content of fatty acids C16:0 and C18:0, which together accounted for more than $90 \%$ of the SFA in this tissue. The similar content of fatty acid C16:0 of the meat is associated with its content in the duodenal digesta. According to Loor et al. (2004), the intestinal digestibility of this fatty acid was not altered by the fraction of concentrate in the diets, while intestinal digestibility of fatty acid C18:0 reduced from $90.9 \%$ in diets with $350 \mathrm{~g}$ concentrate to $75.6 \%$ in diets with 650 $\mathrm{g}$ concentrate. The reduced intestinal absorption of fatty acid C18:0, which represented more than $50 \%$ of the SFA of the duodenal digesta, explains the similar content of this fatty acid in the meat. A reduction in the intestinal absorption of fatty acid C18:0 may also affect the fatty acid profile of the 
meat from a dilution effect, which would explain the increase, in relation to the duodenal digesta, in fatty acids such as C16:0 and C18:1 cis-9. Notably, the SFA of the meat were considered a health risk because of its association with the increase in LDL cholesterol and cardiovascular diseases (JEKINS et al., 2015). The SFA that acts on LDL cholesterol in the plasma have 12 to 16 carbons, of which fatty acid $\mathrm{C} 14: 0$ has the greatest hypercholesterolemic potential, while the fatty acid $\mathrm{C} 16: 0$, which is found in high concentrations in beef, has reduced hypercholesterolemic action (DALEY et al., 2010).
Mean content (49.64\%) of total SFA of the beef in the present study, however, was close to the mean of the pasture-finished animals, possibly associated with the sex and age (14-17 months) of these animals at slaughter. Ito et al. (2012) reported a total SFA of $49.22 \%$ in the meat of young 14-month old bulls finished on Hermarthria altissima with supplement (1.5 kg/day). Bressan et al. (2011) found the mean total SFA contents of $48.58 \%$ and $53.19 \%$ for the total meat of bulls (mean age of 33 months) finished in pasture and feedlot, respectively.

Table 4. Fatty acids profile of meat of young bulls fed concentrate levels.

\begin{tabular}{|c|c|c|c|c|c|c|c|c|}
\hline \multirow{2}{*}{$\begin{array}{l}\text { Items, } \mathrm{g} / 100 \mathrm{~g} \text { fatty acid } \\
\text { methyl esters }\end{array}$} & \multicolumn{4}{|c|}{ Concentrate levels, $\mathrm{g} / \mathrm{kg}$ DM } & \multirow{2}{*}{ SE } & \multicolumn{3}{|c|}{$\mathrm{P}$ - value } \\
\hline & 220 & 400 & 590 & 790 & & $\mathrm{~L}$ & $\mathrm{Q}$ & $\mathrm{C}$ \\
\hline \multicolumn{9}{|l|}{ Saturated fatty acids (SFA) } \\
\hline $\mathrm{C} 14: 0$ & 2.65 & 2.19 & 1.42 & 2.68 & 16.88 & 0.807 & 0.186 & 0.546 \\
\hline $\mathrm{C} 15: 0$ & 0.37 & 0.12 & 0.32 & 0.40 & 0.10 & 0.499 & 0.114 & 0.792 \\
\hline $\mathrm{C} 16: 0$ & 25.09 & 24.02 & 22.33 & 26.55 & 3.81 & 0.773 & 0.133 & 0.117 \\
\hline $\mathrm{C} 17: 0$ & 0.96 & 0.77 & 0.84 & 0.96 & 0.10 & 0.940 & 0.031 & 0.354 \\
\hline C18:0 & 18.91 & 17.58 & 19.07 & 17.02 & 2.58 & 0.438 & 0.634 & 0.409 \\
\hline \multicolumn{9}{|c|}{ Monounsaturated fatty acids (MUFA) } \\
\hline C16:1 & 2.94 & 2.35 & 1.88 & 3.33 & 14.86 & 0.210 & 0.124 & 0.361 \\
\hline C18:1 cis-9 & 29.01 & 35.03 & 32.70 & 33.15 & 3.75 & 0.163 & 0.241 & 0.409 \\
\hline C18:1 trans -11 & 1.07 & 0.91 & 1.08 & 1.47 & 18.68 & 0.061 & 0.051 & 0.734 \\
\hline C20:1 & 0.13 & 0.02 & 0.09 & 0.19 & 0.07 & 0.247 & 0.055 & 0.352 \\
\hline \multicolumn{9}{|c|}{ Polyunsaturated fatty acids (PUFA) } \\
\hline $\mathrm{C} 18: 2$ cis-6 & 4.87 & 4.50 & 4.65 & 4.00 & 26.98 & 0.303 & 0.357 & 0.973 \\
\hline C18:3 n-3 & 0.34 & 0.36 & 0.22 & 0.17 & 15.15 & 0.053 & 0.690 & 0.349 \\
\hline C18:2 cis-9 trans-11 & 0.18 & 0.32 & 0.23 & 0.19 & 7.10 & 0.787 & 0.028 & 0.078 \\
\hline $\mathrm{C} 20: 3 n-6$ & 0.37 & 0.30 & 0.34 & 0.22 & 6.18 & 0.049 & 0.917 & 0.641 \\
\hline $\mathrm{C} 20: 4 n-6$ & 1.32 & 1.17 & 1.05 & 0.60 & 8.49 & 0.046 & 0.232 & 0.557 \\
\hline C20:5 n-3 EPA & 0.24 & 0.09 & 0.00 & 0.00 & 9.17 & 0.042 & 0.388 & 0.994 \\
\hline $\mathrm{C} 22: 5 n-6$ & 0.22 & 0.13 & 0.00 & 0.00 & 17.19 & 0.081 & 0.879 & 0.285 \\
\hline \multicolumn{9}{|c|}{ Total fatty acids and interrelations } \\
\hline Total SFA & 51.37 & 47.44 & 49.74 & 49.99 & 8.77 & 0.929 & 0.246 & 0.697 \\
\hline Total MUFA & 35.06 & 36.97 & 37.37 & 38.91 & 9.26 & 0.133 & 0.977 & 0.863 \\
\hline Total PUFA & 7,13 & 7,99 & 6,38 & 4,85 & 2.19 & 0.117 & 0.605 & 0.216 \\
\hline Total UFA & 39.41 & 48.18 & 43.53 & 43.95 & 6.95 & 0.717 & 0.343 & 0.976 \\
\hline$n-6 / n-3$ & 11.91 & 10.87 & 15.25 & 17.80 & 21.18 & 0.134 & 0.774 & 0.867 \\
\hline
\end{tabular}

$\mathrm{C} 17: 0=1.222+0.0078 \mathrm{M}-0.019 \mathrm{CL}+0.00019 \mathrm{CL}^{2} ; \mathrm{C} 18: 1$ trans-11 $=0.905-0.011 \mathrm{M}+0.0072 \mathrm{CL} ; \mathrm{C} 18: 2$ cis -9 trans $-11=-0.0064$ $+0.01126 \mathrm{CL}-0.00011 \mathrm{CL}^{2} ; \mathrm{C} 18: 3 n-6=0.5335-0.01545 \mathrm{M}-0.00266 \mathrm{CL} ; \mathrm{C} 20: 4 n-6=1.944-0.044 \mathrm{M}-0.013 \mathrm{CL} ; \mathrm{C} 20: 5 n-3$ $\mathrm{EPA}=0.33-0.0058 \mathrm{M}-0.0043 \mathrm{CL} ; \mathrm{M}$, marbling; CL, concentrate level; SE, standard error; L, linear effect; Q, quadratic effect; C, cubic effect. 
The content of fatty acid C18:1 trans-11 of the meat increased linearly $(\mathrm{P}<0.05)$ as the levels of concentrate in the diet increased, but, the sum of MUFA was not altered $(\mathrm{P}>0.05)$ by the diets (Table 4). The similar content of fatty acid C16:1 of the meat can be associated with the similar content of fatty acid C16:0 in duodenal digesta (Table 3) since the first is produced by desaturation of second (CARTA et al., 2017). Similarly, the content of fatty acid C18:1 cis-9 of the meat can be associated with the similar content of this fatty acid in the duodenal digesta (Table 4). In contrast, variation in the content of fatty acids C18:1 trans-11 and C18:2 cis-9 trans-11 of the meat indicate greater activity of the enzyme $\mathrm{D}^{9}$-desaturase, responsible for endogenous synthesis of fatty acid C18:2 cis9 trans-11 (CLA) from the fatty acid trans-11 vaccenic acid (GLASSER et al., 2008). This finding can be confirmed by the higher content of CLA of the meat in the diets with $400 \mathrm{~g}$ of concentrate (Table 4 ), although these results were just a statistical trend $(\mathrm{P}=0.078)$.

The content of fatty acid C18:2 cis-9 trans-11 of the meat showed a quadratic variation $(\mathrm{P}<0.05)$ with an increase in the level of concentrate in the diets, with the highest values observed for the diets with $400 \mathrm{~g}$ of concentrate (Table 4). This result can be linked to several factors. According to the literature (GLASSER et al., 2008; VAHMANI et al., 2015), these factors include PUFA consumption, intensity of the rumen biohydrogenation, D9desaturase activity in the tissue, and intestinal absorption. However, the increase in CLA of the meat is beneficial to human health, as it is associated with reducing carcinogenesis, atherosclerosis, and diabetes (DALEY et al., 2010).

The fatty acids, C18:3n-3 and C22:5n-6, of the meat tended $(\mathrm{P}<0.10)$ to decrease as the levels of concentrate in the diet increased (Table 4). On the other hand, the increasing levels of concentrate in the diets linearly reduced $(\mathrm{P}<0.05)$ the content of fatty acids, C20:3 n-6, C20:4 n-6, and C20:5 n-3 (eicosapentaenoic acid - EPA) of the meat. The fatty acids C20:3n-6, C20:4 n-6, and C20:5 n-3 EPA are synthesized from fatty acids C18:2 cis- 6 and C18:3 $n$-3 during rumen biohydrogenation (MARTIN et al., 1999); in this study, rumen biohydrogenation decreased as the levels of concentrate in the diet increased, thus justifying the results obtained in the present study. The similar content of fatty acid C18:2 cis-6 of the meat is consistent, since reduced biohydrogenation of this fatty acid may have compensated for the reduced content in the diets. According to Glasser et al. (2008), the fatty acid C18:1 trans-11 is mostly formed from fatty acid C18:2 cis-6 in relation to fatty acid C18:3n-3, suggesting that the reduction of fatty acid C18:3n-3 in the meat as the levels of concentrate increased may be associated with its reduced content in the diet. Reduction in the content of fatty acid C18:3 $n-3$ of the meat, which is an essential fatty acid and precursor of $\omega-3$ fatty acids, is undesirable, because it maintains the structure of cell membranes, brain function, and the transmission of nerve impulses. Moreover, the fatty acids C20:4 n-6 and C20:5 $n-3$ are precursors of eicosanoids (prostaglandins, thromboxanes, leukotrienes), that have important physiological and regulatory functions (SIMOPOULOS, 2010).

The absence of variations in content of MUFA, PUFA and UFA (Table 4) of the meat can be attributed to the content of fatty acids C18:1 cis9 and C18:2 cis-6, which together accounted for more than $85 \%$ of UPA, and individually accounted for more than $74 \%$ of MUFA, and $82 \%$ of PUFA of the meat. These results can be associated with the low variation in intestinal digestibility of fatty acid cis-C18:1, which, according to Loor et al. (2004), was only $4 \%$ higher with the increase of $85.7 \%$ in the concentrate content in the diets. The similar content of fatty acid C18:2 cis-6 of the meat, however, can be associated with increased intestinal absorption as the levels of concentrate increased (KUCUK et al., 2001), which possibly contrasts with the reduced content in diets with a higher level of concentrate. The higher intestinal disappearance 
of UFA in relation to SFA is associated with the greater hydrophobicity of UFA (MINICH et al., 1997).

The relationship between fatty acids $\omega-6$ and $\omega-3$ of the meat was consistent in the diets due to the reduction in both fatty acid groups with increasing levels of the concentrate. Fatty acids of the $\omega-3$ and $\omega-6$ family are important in the human diet because they are not synthesized de novo. They are also the precursors of PUFA, responsible for the synthesis of eicosanoids associated with the immune system and inflammatory responses. The ratio between consumption of fatty acids $\omega-3$ and $\omega-6$ are related to the prevention of a series of diseases is approximately $3: 1$ to $4: 1$ (SIMOPOULOS, 2010). The mean $\omega-6 / \omega-3$ ratio was $14: 1$, which may be considered high. Large amounts of fatty acids $\omega-6$ in the human diet can increase the production of eicosanoids, which, in excessive amounts, may increase the risk of inflammation and autoimmune disorders like diabetes, hypertension, and arthritis (VAHMANI et al., 2015).

\section{Conclusion}

The increasing levels of concentrate compromises the profile of polyunsaturated fatty acids of the duodenal digesta and meat, considered essential to human health. This negatively affects the nutritional quality of meat of very young bulls.

\section{References}

BLIGH, E. G.; DYER, W. J. A rapid method of total lipid extraction and purification. Canadian Journal of Biochemistry and Physiology, Ottawa, v. 37, n. 8, p. 911917, 1959.

BRESSAN, M. C.; ROSSATO, L. V.; RODRIGUES, E. C.; ALVES, S. P.; BESSA, R. J. B.; RAMOS, E. M.; GAMA, L. T. Genotype $\times$ environment interactions for fatty acid profiles in Bos indicus and Bos taurus finished on pasture or grain. Journal of Animal Science, Champaign, v. 89, n. 1, p. 221-232, 2011. DOI: $10.2527 /$ jas.2009-2672
CARTA, G.; MURRU, E.; BANNI, S.; MANCA, C. Palmitic acid: physiological role, metabolism and nutritional implications. Frontiers in Physiology, Lausanne v. 8, n. 902, p. 1-14, 2017. DOI: 10.3389/ fphys.2017.00902

DALEY, C.; ABBOTT, A.; DOYLE, P. S.; NADER, G. A.; LARSON, S. A review of fatty acid profiles and antioxidant content in grass-fed and grain-fed beef. Nutrition Journal, Newcastle, v. 10, n. 9, p. 1-12, 2010. DOI: $10.1186 / 1475-2891-9-10$

DUCKETT, S. K.; WAGNER, D. G.; YATES, L. D.; DOLEZAL, H. G.; MAY, S. G. Effects of time on feed on beef nutrient composition. Journal of Animal Science, Champaign, v. 71, n. 8, p. 2079-2088, 1993. DOI: 10.2527/1993.7182079x

FOLCH, J.; LEES, M.; SLOANE STANLEY, G. H. A simple method for the isolation and purification of total lipids from animal tissues. The Journal of Biological Chemistry, Rockville, v. 226, n. 1, p. 497-509, 1957.

GLASSER, F.; SCHMIDELY, P.; SAUVANT, D.; DOREAU, M. Digestion of fatty acids in ruminants: a meta-analysis of flows and variation factors: 2. C18 fatty acids. Animal, London, v. 2, n. 5, p. 691-704, 2008. DOI: $10.1017 / \mathrm{S} 1751731108002036$

HARTMAN, L.; LAGO, R. C. A. Rapid preparation of fatty acid methyl esters from lipids. Laboratory Practice, London, v. 22, n. 6, p. 475-476, 1973.

ITO, R. H.; PRADO, I. N.; ROTTA, P. P.; OLIVEIRA, M. G.; PRADO, R. M.; MOLETTA, J. L. Carcass characteristics, chemical composition and fatty acid profile of longissimus muscle of young bulls from four genetic groups finished in feedlot. Revista Brasileira de Zootecnia, Viçosa, MG, v. 41, n. 2, p. 384-391, 2012. DOI: $10.1590 / \mathrm{S} 1516-35982012000200022$

JEKINS, B; JAMES, A.; KOULMAN, A. A review of odd-chain fatty acid metabolism and the role of pentadecanoic acid (C15:0) and heptadecanoic acid (C17:0) in health and disease. Molecules, Basel, v. 20, n. 2, p. 2425-2444, 2015. DOI: 10.3390/molecules20022425

KOOHMARAIE, M.; WHEELER, T. L.; SHOCKELFORD, S. D. Sampling, cooking and coring effects on Warner-Bratzler shear force values in beef. Journal of Animal Science, Champaign, v. 74, n. 7, p. 553-1562, 1996. DOI: 10.2527/1996.7471553x

KREHBIEL, C. R.; CRANSTON, J. J.; McCURDY, M. P. An upper limit for caloric density of finishing diets. Journal of Animal Science, v. 84, p. 34-49, 2006. Supplement Special. DOI: 2006.8413_supplE34x 
KUCUK, O.; HESS, B. W.; LUDDEN, P. A.; RULE, D. C. Effect of forage: concentrate ratio on ruminal digestion and duodenal flow of fatty acids in ewes. Journal of Animal Science, Champaign, v. 79, n. 8, p. 2233-2240, 2001. DOI: $10.2527 / 2001.7982233 x$

LITTELL, R. C.; MILLIKEN, G. A.; STROUP, W. W.; WOLFINGER, R. D.; SCHABENBERGER, O. SAS® for mixed models. $2^{\text {ht }}$ ed. Cary: SAS Institute Inc., 2006. $814 \mathrm{p}$.

LOFTEN, J. R.; LINN, J. G.; DRACKLEY, J. K.; JENKINS, T. C.; SODERHOL, C. G.; KERTZ, A. F. Invited review: palmitic and stearic acid metabolism in lactating dairy cows. Journal of Dairy Science, Champaign, v. 97, n. 8, p. 1-14, 2014. DOI: 10.3168/ jds.2014-7919

LOOR, J. J.; UEDA, K.; FERLAY, A.; CHILLIARD, Y.; DOREAU, M. Biohydrogenation, duodenal flow, and intestinal digestibility of trans fatty acids and conjugated linoleic acids in response to dietary forage:concentrate ratio and linseed oil in dairy cows. Journal of Dairy Science, Champaign, v. 87, n. 8, p. 2472-2485, 2004. DOI: $10.3168 /$ jds.S0022-0302(04)73372-X

MARTIN, G. S.; LUNT, D. K.; BRITAIN, K. G.; SMITH, S. B. Postnatal development of stearoyl coenzyme A desaturase gene expression and adiposity in bovine subcutaneous adipose tissue. Journal of Animal Science, Champaign, v. 77, n. 3, p. 630-636, 1999. DOI: 10.2527/1999.773630x

MINICH, D.; VONK, R. J.; VERKADE, H. J. Intestinal absorption of essential fatty acids under physiological and essential fatty acid-deficient conditions. The Journal of Lipid Research, Rockville, v. 38, n. 9, p. 1709-1721, 1997.

MISSIO, R. L.; RESTLE, J.; FREITAS, A. K.; LAGE, M. E.; PACHECO, P. S.; BILEG, U. O.; PADUA, J. T. Age castration of Nellore males on the profile of fatty acids of meat. Semina: Ciências Agrárias, Londrina, v. 38, n. 6, p. 3739-3748, 2017. DOI: 10.5433/1679-0359.2017v3 8n6p3739
PEDREIRA, M. S.; OLIVEIRA, S. G.; PRIMAVESI, O.; LIMA, M. A.; FRIGHETTO, R. T. S.; BERCHIELLI, T. T. Methane emissions and estimates of ruminal fermentation parameters in beef cattle fed different dietary concentrate levels. Revista Brasileira de Zootecnia, Viçosa, MG, v. 42, n. 8, p. 592-598, 2013. DOI: $10.1590 / \mathrm{S} 1516-35982013000800009$

RESTLE, J.; MISSIO, R. L.; RESENDE, P. L. P.; SILVA, N. L. Q.; VAZ, V. N.; BRONDANI, I. L.; ALVES FILHO, D. C.; KUSS, F. Silagem de híbridos de sorgo associado a percentagens de concentrado no desempenho de novilhos. Arquivo Brasileiro de Medicina Veterinária e Zootecnia, Belo Horizonte, v. 64, n. 5, p. 1239-1245, 2012. DOI: $10.1590 / \mathrm{S} 0102-09352012000500023$

SIMOPOULOS, A. P. The omega-6/omega-3 fatty acid ratio: health implications. Oilseeds and fats Crops and Lipids, Paris, v. 17, n. 5, p. 267-275, 2010. DOI: 10.1051/ ocl.2010.0325

SMITH, S. B.; GILL, C. A.; LUNT, D. K.; BROOKS, M. A. Regulation of fat and fatty acid composition in beef cattle. Asian-Australasian Journal of Animal Sciences, Seoul, v. 22, n. 9, p. 1225-1233, 2009. DOI: 10.5713/ ajas.2009.r.10

VAHMANI, P.; MAPIYE, C.; PRIETO, N.; ROLLAND, D. C.; MCALLISTER, T. A.; AALHUS, J. L.; DUGAN, M. E. R. The scope for manipulating the polyunsaturated fatty acid content of beef: a review. Journal of Animal Science and Biotechnology, London, v. 6, n. 1, p. 2-13, 2015. DOI: $10.1186 / \mathrm{s} 40104-015-0026-Z$

VLAEMINCK, B.; FIEVEZ, V.; CABRITA, A. R. J.; FONSECA, A. J. M.; DEWHURST, R. J. Factors affecting odd- and branched-chain fatty acids in milk: a review. Animal Feed Science and Technology, New York, v. 131, n. 3, p. 389-417, 2006. DOI: 10.1016/j. anifeedsci.2006.06.017

XUE, S.; HE, Z.; LU, J.; TAO, X.; ZHENG, L.; XIE, Y.; XIAO, X.; PENG, R.; LI, H. Effect of growth on fatty acid composition of total intramuscular lipid and phospholipids in Ira rabbits. Korean Journal for Food Science of Animal Resources, Seoul, v. 35, n. 1, p. 10-18, 2015. DOI: $10.5851 /$ kosfa.2015.35.1.10 
